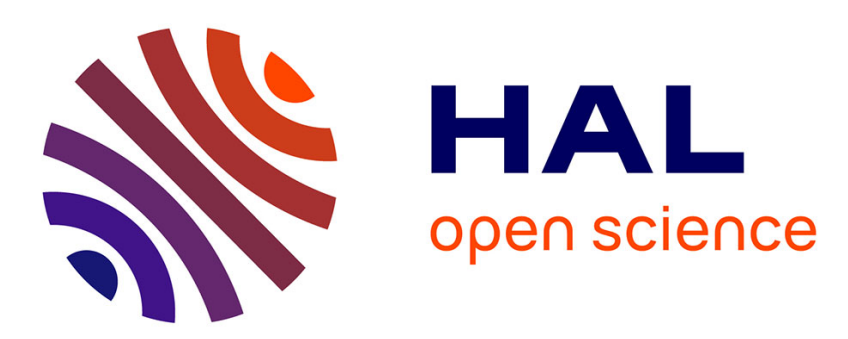

\title{
G-protein coupled receptors mediating long chain fatty acid signalling in the pancreatic beta cell
}

\author{
Noel G. Morgan, Shalinee Dhayal
}

\section{To cite this version:}

Noel G. Morgan, Shalinee Dhayal. G-protein coupled receptors mediating long chain fatty acid signalling in the pancreatic beta cell. Biochemical Pharmacology, 2009, 78 (12), pp.1419. 10.1016/j.bcp.2009.07.020 . hal-00527656

\section{HAL Id: hal-00527656 https://hal.science/hal-00527656}

Submitted on 20 Oct 2010

HAL is a multi-disciplinary open access archive for the deposit and dissemination of scientific research documents, whether they are published or not. The documents may come from teaching and research institutions in France or abroad, or from public or private research centers.
L'archive ouverte pluridisciplinaire HAL, est destinée au dépôt et à la diffusion de documents scientifiques de niveau recherche, publiés ou non, émanant des établissements d'enseignement et de recherche français ou étrangers, des laboratoires publics ou privés. 


\section{Accepted Manuscript}

Title: G-protein coupled receptors mediating long chain fatty acid signalling in the pancreatic beta cell

Authors: Noel G. Morgan, Shalinee Dhayal

PII: $\quad$ S0006-2952(09)00669-8

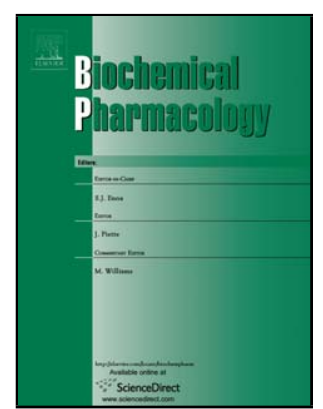

DOI: doi:10.1016/j.bcp.2009.07.020

Reference:

BCP 10275

To appear in: $\quad B C P$

Received date: $\quad$ 16-6-2009

Revised date: 27-7-2009

Accepted date: $\quad$ 27-7-2009

Please cite this article as: Morgan NG, Dhayal S, G-protein coupled receptors mediating long chain fatty acid signalling in the pancreatic beta cell, Biochemical Pharmacology (2008), doi:10.1016/j.bcp.2009.07.020

This is a PDF file of an unedited manuscript that has been accepted for publication. As a service to our customers we are providing this early version of the manuscript. The manuscript will undergo copyediting, typesetting, and review of the resulting proof before it is published in its final form. Please note that during the production process errors may be discovered which could affect the content, and all legal disclaimers that apply to the journal pertain. 
G-protein coupled receptors mediating long chain fatty acid signalling in the pancreatic beta cell

\author{
Noel G. Morgan and Shalinee Dhayal
}

Institute of Biomedical \& Clinical Science, Peninsula Medical School, Plymouth PL6 8BU, UK.

Correspondence: Prof Noel G Morgan

Institute of Biomedical \& Clinical Science

John Bull Building

Peninsula Medical School

Plymouth PL6 8BU, UK

Tel: $+44-(0) 1752-437412$

Email: noel.morgan@pms.ac.uk

Keywords: Diabetes; palmitate; palmitoleate; lipotoxicity; insulin secretion 


\begin{abstract}
It is increasingly clear that some of the effects of both free and derivatised long chain fatty acids in pancreatic beta-cells are mediated by a group of G-protein coupled receptors. Some of these display close structural homology while others are more divergent. This Commentary reviews the expression and functional roles of three such molecules, GPR40, GPR119 and GPR120. GPR40 is the best characterised of this group and appears to mediate the acute stimulatory effects of long chain fatty acids on insulin secretion. GPR40 has also been proposed as a potential mediator of fatty acid toxicity but this is more controversial. GPR119 is also involved in stimulation of insulin secretion and responds primarily to ethanolamine derivatives of long chain fatty acids and also to some lysophospholipids rather than to free fatty acids. It may represent a useful target for the development of new insulin secretagogues aimed to enhance insulin release in patients with type 2 diabetes. GPR120 is the most enigmatic of the lipid responsive cell-surface receptors and its function remains to be established. It has been proposed to play a cytoprotective role in certain other cell types but it is unclear whether it fulfils a similar function in beta-cells.
\end{abstract}

\title{
Introduction
}

It has long been appreciated that free fatty acids can serve as metabolic substrates in the pancreatic $\beta$-cell and that they are able to regulate the secretory activity of these cells by coordinating the oxidation of relevant fuel molecules within the mitochondria [1]. It has also been proposed that fatty acids can subserve more specific intracellular signalling functions by, for example, altering the formation of acyl-CoA species within $\beta$-cells or, in the case of arachidonic acid, by modulating the availability of lipoxygenase and/or cyclo-oxygenasederived metabolites [2]. In addition, excessively high concentrations of free fatty acids exert detrimental effects on $\beta$-cells in that they cause both a loss of glucose-induced insulin secretion and a subsequent decline in cell viability [3;4]. As such, elevated levels of circulating fatty acids may contribute to the decline in glucose homeostasis seen in patients with type 2 diabetes [5-7].

Until recently, it was considered that fatty acids must enter the $\beta$-cell in order to elicit the majority of their effects. However, it is now clear that these molecules can also exert important signalling functions by acting more directly from the extracellular environment. This is because $\beta$-cells express, on their surface, various members of a family of G-protein coupled receptors that can bind fatty acids in the extracellular space and which transmit signals to the intracellular environment. These molecules were originally identified as orphan 
receptors during scans of the genome for putative receptor sequences but it is now established that their endogenous ligands are free fatty acids and/or fatty acid derivatives. Such receptors are implicated in mediating at least part of the stimulatory actions of free fatty acids on insulin secretion and they have also been proposed as mediators of altered $\beta$-cell viability in type 2 diabetes. The present commentary aims to summarise some of the recent evidence and ongoing controversies relating to these conclusions but readers are also pointed to a range of additional review articles which deal with aspects of the topic from different perspectives [8-13]. It is also important to note that intracellular fatty acid receptors are present in $\beta$-cells (including, for example, members of the PPAR family [14]) but that their contribution will not be considered here.

The family of G-protein coupled free fatty acid receptors includes one group of molecules which share a moderate degree of structural homology and whose genes are all located within a closely aligned region of human chromosome 19 (19q13.1) [15]. These proteins display the typical seven-transmembrane domain organisation of G-protein coupled receptors and were originally termed GPR $40,41 \& 43$ before their endogenous ligands were known. They have since been re-designated FFA1, 3 and 2 respectively [16] but, for ease of identification in the literature references cited, the original designation will be retained here. Human chromosomal region 19q13.1 also contains an additional gene which is highly homologous to GPR43 and was originally termed GPR42. However, this is now thought to represent a pseudogene that is unlikely to be expressed as a functional protein [17]. GPR40 is abundantly expressed in pancreatic $\beta$-cells (see below) but GPR41 may be predominantly localised on immune cells [18] and GPR43 on adipocytes [19]. In addition to these molecules, certain structurally more divergent receptors whose ligands are free or derivatised fatty acids are encoded elsewhere in the genome, including GPR84, GPR119 and GPR120 [20-22].

The present Commentary will focus on lipid-responsive G-protein coupled receptors that are likely to influence pancreatic $\beta$-cell function; notably GPR40, GPR119 \& GPR120.

\section{GPR40}

GPR40 is the best-studied of the cell surface receptors for fatty acids expressed on $\beta$-cells and it is strongly implicated in the regulation of insulin secretion. This receptor may also play a role in mediating the detrimental effects of fatty acids on $\beta$-cell function (termed "lipotoxicity") but this remains a controversial topic that is not fully resolved. 


\section{Expression of GPR40}

There is a firm consensus that GPR40 is expressed in $\beta$-cells and this has been confirmed at the mRNA level in a range of species including mouse [23], rat [24] and man [25]. Definitive proof of $\beta$-cell GPR40 protein production has been harder to provide, but this is due mainly to the lack of fully reliable antisera capable of detecting the molecule on Western blots or by immunohistochemistry. However, a recent report has described the successful generation of a monoclonal antibody directed against a peptide localised within the $\mathrm{N}$ terminal region of human and mouse GPR40 [26]. This antibody labelled some (but, apparently, not all) insulin-positive cells in sections of mouse pancreas, consistent with the expression of GPR40 on $\beta$-cells. The antibody did not co-localise with anti-glucagon staining suggesting that GPR40 may not be expressed on $\alpha$-cells. A similar conclusion had already been drawn on the basis of in situ hybridisation analysis of rat islet sections (where labelling of $\beta$-cells was evident and $\alpha$-cells appeared negative [27]) but this view contrasts sharply with the findings of Flodgren et al [28] who used a different antiserum to GPR40 to reveal the presence of this receptor on a-cells in mouse pancreas. Clearly, further work is required to clarify the situation and to establish whether species differences might account for the divergent results obtained to date for expression of GPR40 in a-cells.

The discovery that GPR40 is abundantly expressed in $\beta$-cells has prompted an analysis of the factors regulating expression of the receptor [29;30]. In mice, the gene consists of 2 exons spanning 24 and $4402 \mathrm{bp}$ respectively, of which the first is non-coding while the second specifies the full coding sequence. The two exons are separated by a $698 \mathrm{bp}$ intron which is spliced out during RNA processing. Upstream of the first exon are several regulatory sites which appear to be responsible for directing the expression of the gene in $\beta$ cells since reporter constructs derived from this region showed marked regulatory potential when expressed in $\beta$-cells but not in $\mathrm{CHO}$ cells [31]. In particular, a region designated HR2 contains an E-box element that binds the helix-loop-helix transcription factor, BETA2, and it also encodes a consensus site for the homeodomain protein PDX-1. Both of these transcription factors are considered to be critical for determination of the $\beta$-cell phenotype. In addition, PDX-1 may also drive the expression of certain proteins within intestinal neuroendocrine cells and recent evidence suggests that GPR40 is expressed by both K [32] and L-cells [33] in the gut. As such, it may play a role in sensing ingested fat within the intestinal lumen and thereby contribute to the incretin-effect by promoting the release of peptides such as glucagon-like-peptide-1 (GLP-1) and glucose-dependent insulinotropic 
polypeptide (GIP) into the circulation. These agents can then impinge on the $\beta$-cell to enhance insulin secretion and it seems likely, therefore, that fatty acids may exert both indirect (via incretin release) and direct (via FFA receptors expressed on $\beta$-cells) stimulatory effects on insulin release. In both cases, of course, FFA receptors serve as the primary sensor of fatty acid availability.

\section{Ligand specificity of GPR40}

GPR40 appears to possess a relatively wide substrate specificity in that it is activated by saturated fatty acids having chain lengths from as few as 10 carbon atoms (capric acid) to at least 23 (tricosanoic acid) as well as by various mono- (e.g. palmitoleic (C16:1) and oleic (C18:1) acids) and poly-unsaturated fatty acids (e.g. linoleic (C18:2) and eicosatrienoic (C20:3) acids) [34-36]. The potency of these species varies but the $E_{50}$ values for activation of the ectopically expressed human receptor by different fatty acids are, typically, in the $\mu \mathrm{M}$ range. This suggests that GPR40 could be activated by free concentrations of fatty acids within the physiological range. In drawing this conclusion, it is important to emphasise that, under most experimental conditions, the free concentration of fatty acids available for receptor binding is several orders of magnitude lower than the total concentration, since the majority of fatty acid molecules are complexed to proteins (such as serum albumin) present in the incubation medium.

In order to serve as an agonist at GPR40, a free carboxyl group appears to be required in the fatty acid ligand since the methyl ester of linoleate is inactive whereas unesterified linoleate activates the receptor with an $\mathrm{EC}_{50}$ of $\sim 2 \mu \mathrm{M}$ [37]. This conclusion has been confirmed by initial structural analysis which implies the existence of a 3-dimensional cluster of residues in the human receptor which specifically coordinate the carboxylate group of ligands [38]. These amino acids, $\operatorname{Arg}^{183}, \mathrm{Asn}^{244}$ and $\mathrm{Arg}^{258}$, are located close to the extracellular domains of the three most distal transmembrane regions (TM5, 6 and 7) suggesting that ligand binding may occur close to, or within, the plane of the membrane; as might be expected for ligands which are predominantly hydrophobic. Interestingly, a range of low molecular weight, non-fatty acid, agonists of GPR40 have been developed and many (but not all; see below) of these molecules retain a free carboxylate group, suggesting that these synthetic ligands may bind to the receptor in a similar manner to fatty acids [39].

Recent evidence derived from molecular modelling and in vitro mutagenesis [40] indicates that two critical glutamic acid residues in the $3^{\text {rd }}$ extracellular loop ( $\mathrm{Glu}^{145}$ and $\mathrm{Glu}^{172}$ ) of GPR40 form an "ionic lock" with 2 of the arginine residues identified above as being required for agonist binding ( $\operatorname{Arg}^{183}$ and $\operatorname{Arg}^{258}$ respectively). This lock maintains the molecule in an 
inactive conformation and is broken upon ligand binding (by coordination of the carboxyl group of the fatty acid ligand with $\mathrm{Arg}^{183}$ and $\mathrm{Arg}^{258}$ ) thereby leading to receptor activation.

In initial studies of the ligand specificity of GPR40, Kotarsky et al. [41] made the interesting observation that certain clinically effective thiazolidinediones can activate the receptor with $\mu \mathrm{M}$ potency. In support of this, a recent report has demonstrated that thiazolidinediones can elicit proliferative responses in human bronchial epithelial cells via GPR40 [42]. Moreover, Tan et al [43] have substantiated the concept by describing a range of modified thiazolidinedione-derivatives that retain agonist activity at GPR40 but which display $\mathrm{EC}_{50}$ values as low as $15 \mathrm{nM}$ in transfected cell experiment. Since these reagents lack the free carboxyl group of native fatty acids it seems probable that they may bind to the receptor via different coordination sites but, nevertheless, they appear to retain full agonist activity.

Whether any of the beneficial effects of the currently available thiazolidinediones in patients with type 2 diabetes reflects an action on $\beta$-cell GPR40 remains to be established. However, this seems improbable given that their potency as PPARy ligands is some 1000 -fold higher than their reported $\mathrm{EC}_{50}$ values for interaction at GPR40. Nevertheless, it is conceivable that a new generation of thiazolidinediones drugs, specifically targeted to GPR40, might have therapeutic benefit in type 2 diabetes. In support of this, Tan et al show that one of their newly-developed thiazolidinedione GPR40 agonists caused an improvement in blood glucose excursion during an intraperitoneal glucose tolerance test in mice maintained on a high fat diet to simulate obesity-induced changes to $\beta$-cell responsiveness [44]. This compound also restored the first phase of glucose-induced insulin release from the islets of animals previously rendered diabetic with streptozotocin.

Signal transduction mechanisms of GPR40

As indicated above, there is a strong consensus that GPR40 is expressed abundantly on pancreatic $\beta$-cells and that it is coupled to intracellular signalling systems which regulate insulin exocytosis. Initial data, obtained in cultured cells transfected with GPR40, revealed that appropriate agonists elicited a rapid and large rise in intracellular free [Ca] $\left(\left[\mathrm{Ca}_{i}\right]\right)[45 ; 46]$ and similar data were also reported in pancreatic $\beta$-cell lines $[47 ; 48]$ and in primary islet cells [49]. This response was accompanied by a marked, glucose-dependent, increase in insulin secretion suggesting that the amplifying actions of fatty acids on insulin release may be mediated, at least in part, by changes in $\left[\mathrm{Ca}_{i}\right]$ deriving from activation of GPR40. These responses are insensitive to pertussis toxin, suggesting that that GPR40 does not couple to Gi/Go in $\beta$-cells [50]. In transfected HEK293 cells, the GPR40 agonist, linoleic acid, promoted the hydrolysis of inositol lipids in a manner which is consistent with the activation of phospholipase C via a Gq mediated mechanism [51]. Breakdown of inositol lipids has not 
been studied directly in $\beta$-cells exposed to GPR40 agonists but the rise in $\beta$-cell $\left[\mathrm{Ca}_{i}\right]$ that accompanies fatty acid treatment is consistent with the involvement of PLC. In support of this, Shapiro et al [52] observed that the rise in [Cai $]$ caused by palmitate in INS-1E cells was attenuated by chemical inhibitors of PLC and Latour and colleagues noted that PLC inhibitors also attenuate the acute elevation of insulin secretion mediated by palmitate in isolated mouse islets [53]. However, whether the rise in GPR40-induced cytosolic Ca derives entirely from intracellular stores remains to be established and there is some evidence that this may not be the case. Thus, in their original description of the actions of GPR40, Itoh et al observed that the rise in $\left[\mathrm{Ca}_{i}\right]$ induced by fatty acids in MIN6 cells was inhibited by the Ltype Ca channel blocker, nifedipine, suggesting some involvement of a Ca influx mechanism [54]. However, nifedipine did not prevent the earliest phase of the increase in [ $\left.\mathrm{Ca}_{i}\right]$ seen under these conditions implying that both early intracellular Ca mobilisation as well as a later influx from the extracellular milieu, may be required for full development of the Ca signal and of the subsequent insulin secretory response.

Classically, it is considered to be the case that receptors coupled to $\mathrm{Gq}$ cause the mobilisation of intracellular Ca from stores localised within the endoplasmic reticulum (ER). Consistent with this, Feng et al [55] observed that prior depletion of ER Ca stores with thapsigargin resulted in the failure of the GPR40 agonist, linoleic acid, to elevate $\left[\mathrm{Ca}_{i}\right]$ in primary rat $\beta$-cells. By contrast, Gwiazda and colleagues observed that treatment of MIN6 cells with palmitate (which also elevated $\left[\mathrm{Ca}_{i}\right]$ via GPR40 in these cells) did not lead to sustained depletion of ER Ca stores since subsequent addition of the muscarinic cholinergic agonist, carbachol, still elicited a rise in $\left[\mathrm{Ca}_{i}\right]$ despite the continued presence of palmitate [56]. Since GPR40 does not appear to be subject to short-term desensitisation in $\beta$-cells, these results imply that activation of this receptor by palmitate causes only a partial release of $\mathrm{ER} \mathrm{Ca}$ in $\beta$-cells and/or that this $\mathrm{Ca}$ is retained in a compartment different from that accessed upon stimulation of the cells with carbachol. Further work will be required to distinguish between these possibilities but, currently, it seems likely that activation of PLC and the subsequent generation of inositol 1,4,5 trisphosphate may not be the sole mechanism by which GPR40 causes a rise in $\beta$-cell $\left[\mathrm{Ca}_{\mathrm{i}}\right]$.

One possible alternative mechanism by which GPR40 may elevate $\left[\mathrm{Ca}_{\mathrm{i}}\right]$ is offered by the demonstration that this receptor regulates the gating of voltage-dependent K-channels in $\beta$ cells [57]. These channels play a role in repolarisation of the plasma membrane during glucose stimulation and, as such, they facilitate the closure of voltage sensitive Ca channels and contribute to the lowering of cytosolic Ca levels. Feng et al [58] have presented evidence that the gating of voltage-gated $\mathrm{K}$ channels is impaired upon stimulation of GPR40 and that this then serves to prolong the opening of voltage sensitive $\mathrm{Ca}$ channels and to 
maintain cytosolic $\mathrm{Ca}$ at an elevated level. This action would, therefore, sustain $\left[\mathrm{Ca}_{\mathrm{i}}\right]$ by influencing the influx of extracellular $\mathrm{Ca}$ rather than by promoting the mobilisation of Ca from within the ER. The mechanism by which GPR40 regulates voltage-gated $\mathrm{K}$ channel activity has not been established although the effects of linoleic acid were blocked by protein kinase A inhibitors and reproduced by addition of a cell-permeable analogue of cAMP. On this basis, the authors speculate that GPR40 may couple to adenylate cyclase via Gs thereby leading to a rise in cAMP. However, this conclusion remains to be substantiated since the addition of fatty acids typically causes little or no rise in $\beta$-cell cAMP [59], suggesting that GPR40 does not couple strongly to Gs under most circumstances.

It has recently been reported that at least two single nucleotide polymorphisms (SNPs) can be distinguished in the coding region of the human GPR40 gene which may exert functional effects [60;61]. One of these leads to an amino acid substitution (arginine to histidine) at position 211 in the third intracellular loop of the receptor which was reported to cause enhanced insulin secretion in Japanese males [62], although it was not associated with altered insulin secretion in European populations. A second SNP, located in a region of the coding sequence close to the junction between the second extracellular loop and the $5^{\text {th }} \mathrm{TM}$ region, also results in an amino acid substitution (Gly ${ }^{180} \mathrm{Ser}$ ) [63]. In this case, possession of the less frequent variant $\left(\operatorname{Ser}^{180}\right)$ was associated with elevated body-mass index in Europeans and a reduction in insulin secretion following an oral glucose load. Similarly, insulin secretion was also reduced in this cohort during an oral lipid load. On the basis of in vitro studies in transfected HeLa cells, it was established that the $\operatorname{Ser}^{180}$ variant is processed and expressed at the cell surface normally but that cells expressing this molecule display a reduced rise in cytosolic Ca compared to those expressing the Gly ${ }^{180}$ receptor. Thus, it appears that naturally occurring variants of GPR40 may have differing propensities to elicit a rise in cytosolic $\mathrm{Ca}$ and, possibly, insulin secretion in humans.

Role of GPR40 in lipotoxicity

Although it is increasingly accepted that agonists of GPR40 can promote insulin secretion acutely, the role of the receptor in mediating the longer term deleterious effects of fatty acids on $\beta$-cells ("lipotoxicity") is still a matter of debate. In particular, it is known that prolonged elevation of circulating fatty acids leads to a decline in insulin secretion and, ultimately, to loss of $\beta$-cell viability but there are conflicting views as to the role played by GPR40 in these processes. Initial data were provided by Steneberg and colleagues [64] who generated GPR40 knock-out (KO) mice and observed that, when maintained on a high fat diet, these animals failed to develop the characteristic metabolic abnormalities seen in wild type animals. Specifically, the GPR40 KO animals had lower fasting insulin, greater insulin 
sensitivity and improved glucose tolerance than the animals with normal levels of GPR40 expression. The GPR40 KO animals were also protected against hepatic steatosis during high fat feeding and they did not develop hypertriglyceridaemia. Moreover, following $48 \mathrm{~h}$ exposure of the islets of these animals to palmitate in vitro, their insulin secretory response to glucose was dramatically improved compared to wild type animals. These data provided striking evidence that GPR40 may be required not only for the acute stimulatory effects of fatty acids in $\beta$-cells but also for the longer term detrimental effects. As such, this led to the concept that, from a therapeutic point of view, a selective antagonist of GPR40 might be beneficial as a means to minimise the role of this receptor in causing lipid-induced $\beta$-cell toxicity and such molecules are under development [65].

However, after the initial flush of excitement spawned by the early findings of Steneberg et al [66], the field has become more circumspect since a number of workers have now developed GPR40 KO mice but none has shown the dramatic improvement in phenotype during high fat feeding, reported initially. For example, Kebede et al [67] observed that deletion of GPR40 did not prevent any of the detrimental metabolic effects of a high fat diet in C57BL/6 mice. The mice with reduced expression of GPR40 did, though, display an impaired insulin secretory response to glucose suggesting that this receptor may confer aspects of glucose-responsiveness as well as mediating the stimulatory actions of free fatty acids on insulin secretion. However, the $\mathrm{KO}$ mice were not protected from the metabolic consequences of a lipid-enriched diet. Essentially similar conclusions were reached in an independent study by Lan et al. [68] who tested both moderate (45\% calories from fat) and high $(60 \%$ calories) fat diets in mice with deletions of GPR40 on several genetic backgrounds and reported no consistent improvement in glucose tolerance and no reduction in liver fat accumulation compared to mice expressing GPR40.

Brownlie et al have also examined this topic in a further group of GPR40 KO mice and, consistent with all other reports, they observed that loss of the receptor leads to impaired insulin secretory responses to fatty acids [69]. They also confirmed that deletion of GPR40 failed to prevent hepatic steatosis during high fat feeding. However, when studying the glucose tolerance of animals on a high fat diet, their results were somewhat intermediate between the two extremes seen in other studies. In particular, these authors reported that glucose tolerance was impaired within 1 week of increased fat ingestion in wild type mice but that this did not occur in GPR40 KO animals. However, this difference was not sustained when the time course of the experiment was extended. By way of explanation, the authors noted an unexpected improvement in the glucose tolerance of wild type animals during sustained high fat feeding (for more than 8 weeks) which was associated with a decrease in circulating free fatty acid concentrations. This resulted in a convergence of the data; due 
largely to metabolic improvements in the wild type animals rather than to specific protective actions occurring in the GPR40 KO mice. Overall, they concluded that mice lacking GPR40 may show some protection from the early deleterious effects of elevated circulating fatty acids on glucose tolerance but that this is not associated with any attenuation of liver fat accumulation.

Recently, a line of mice over-expressing GPR40 under the control of an insulin-promoter have been developed [70] and these animals displayed improved oral glucose tolerance as well as enhanced glucose- and fatty-acid stimulated insulin secretion compared to wild type mice. Interestingly, these animals were resistant to the detrimental effects of a high fat diet and, when the transgene was expressed against a genetic background predisposing to type 2 diabetes, enhanced insulin secretion was observed.

Taken together, it seems that further work is still required to provide definitive confirmation, but the emerging consensus favours the view that loss of GPR40 does not protect against the deleterious effects of high fat feeding over the medium to long term. As such, development of antagonists of GPR40 may not prove to be a fruitful therapeutic approach for type 2 diabetes. Conversely, since GPR40 activation leads to enhancement of insulin secretion and improved glucose tolerance, even under conditions of reduced islet cell responsiveness, the development of receptor agonists may be more beneficial as a therapeutic approach in type 2 diabetes. Direct support for this proposition has come from recent studies revealing that a selective GPR40 agonist promotes a glucose-dependent rise in insulin secretion in rats and that this is accompanied by improved glucose tolerance [71].

Before leaving this topic, it is important to also refer to one further aspect of the actions of fatty acids in $\beta$-cells; namely, the observation that certain mono-unsaturated long chain molecules (e.g. palmitoleate and oleate) are much less effective as inducers of lipotoxicity than saturated species. Indeed, at least under in vitro conditions, the mono-unsaturates can exert potent cytoprotective actions which display a structure-activity relationship that is fully consistent with receptor involvement [72;73]. The identity of the putative receptor mediating this response has not been defined but Zhang et al [74] have suggested that GPR40 could play a role. This conclusion was drawn from evidence that knock-down of GPR40 expression in the rodent $\beta$-cell line, NIT-1, by interference RNA technology resulted in an impairment of the ability of oleate to exert a cytoprotective response. However, the known selectivity of GPR40 does not readily accord with a primary involvement of this receptor in mediating cytoprotection. For example, GPR40 is known to be activated by both saturated and unsaturated fatty acids but only the latter are cytoprotective [75]. Furthermore, methylated fatty acids do not activate GPR40 whereas they are equipotent with underivatised molecules 
as mediators of cytoprotection [76]. On this basis, it seems unlikely that GPR40 plays a major role in protecting $\beta$-cells against toxic insults.

\section{GPR119}

Aside from GPR40, arguably the best-studied lipid-responsive G-protein coupled receptor in the $\beta$-cell is GPR119. Unlike GPR40, however, this receptor does not bind fatty acids per se but, rather, it is activated by certain ethanolamide derivatives of these molecules and also by some lysophospholipid species that contain defined fatty acids at the C-1 position $[77 ; 78]$.

The gene for GPR119 is present on the X-chromosome in mammals and a cDNA sequence encoding GPR119 was initially cloned from rat [79]. This was suggested to encode a protein of 468 amino acids but this now seems to have been an over-estimate since in most species (including human) the receptor is encoded by a transcript having an open reading frame of $1008 \mathrm{bp}$, thereby yielding a protein composed of 335 residues.

GPR119 was initially identified as a novel member of the general class of G-protein coupled receptors which had no close homologues, although it was subsequently proposed to possess certain structural similarity with cannabinoid receptors [80]. The validity of this assertion is supported by the observation that, in common with cannabinoid receptors, GPR119 can bind certain fatty acid ethanolamides [81]. Identification of these molecules as potential ligands for GPR119 is significant since such compounds can negatively influence food intake, reduce visceral fat mass and lower body weight in various animal models of obesity [82-84]. In particular, it was known that the $\mathrm{C} 18$ monounsaturated derivative, oleoylethanolamide (OEA) is especially efficacious in this regard and cloning of human GPR119 revealed that OEA is a potent agonist of this receptor [85;86]. By contrast, the more classical cannabinoid agonist, arachidonylethanolamide, was much less potent. This supports the idea that GPR119 is not a cannabinoid receptor and suggests that it may represent an appropriate target for the design of novel, non-cannabinoid, anti-obesity drugs.

In order to evaluate this idea more fully, the distribution of GPR119 expression was examined in mammalian tissues by a number of authors and it was rapidly established that both the endocrine pancreas and certain cells of the GI tract express the receptor [87-92]. It is also possible that GPR119 may be expressed in some brain regions [93].

Inevitably, unequivocal confirmation of the expression of GPR119 at the protein level in any given tissue depends on the availability of a reliable antiserum and, as indicated above for GPR40, such antisera can be difficult to develop for G-protein coupled receptors. Hence, expression is often monitored at the level of mRNA but this can be misleading since the 
correlation between mRNA and protein is rarely perfect. To address this problem, Sakamoto et al [94] used an anti-peptide approach to generate a specific antiserum directed against murine GPR119 and compared the expression pattern with that deduced from RT-PCR analysis of mRNA in various mouse tissues and cell lines. Their antibody was characterised in cells expressing a fusion protein containing yellow fluorescent protein and GPR119 and it was noted that there were discrepancies between the predicted size of the immunoreactive product and the location of bands seen on Western blots of cell extracts. This leaves open the possibility that the antiserum may not have been entirely specific for GPR119 but, nevertheless, the authors went on to use it for immunohistochemical analysis of pancreas. This yielded an unexpected outcome in that GPR119 protein was detected in only a subset of islet endocrine cells; namely, those expressing pancreatic polypeptide. By contrast GPR119 immunoreactivity could not be detected in islet $\alpha$ - or $\beta$-cells despite clear evidence that mRNA encoding GPR119 is present in both clonal $\alpha$-cells ( $\alpha$-TC) and $\beta$-cells (MIN6). The authors concluded that the reported expression of GPR119 mRNA in various clonal islet $\beta$-cells (which include NIT-1[95] \& HIT-T15 [96] in addition to MIN6) may be representative of an immature phenotype. This proposal requires further confirmation but it is interesting to note that GPR119 is reportedly absent from the rat $\beta$-cell line RINm5F [97;98] consistent with the possibility that GPR119 is not universally present in mammalian $\beta$-cells.

The conclusion that mature $\beta$-cells may not express GPR119 is contentious and is at variance with the results of a study which employed in situ hybridisation to demonstrate the presence of mRNA encoding GPR119 in both $\alpha$ - and $\beta$-cells of the rat [99]. These workers also developed their own antibody to GPR119 and used this to confirm the co-localisation of GPR119 with insulin in normal rat and mouse islets. These results stand in marked contrast to those of Sakamoto et al [100] but, importantly, the islets of mice which were genetically deficient in GPR119 did not stain positively with the antiserum raised by Chu et al, thereby providing strong support for the reported specificity of their antibody.

\section{Signal transduction mechanism of GPR119}

One area which has generated essentially complete concordance of opinion relates to the signal transduction system used by GPR119. Ectopic expression of GPR119 in various easily transfected cell lines has yielded unanimous support for the view that activation of the receptor is associated with a rise in cAMP levels [101-104]. Moeover, exposure of cultured $\beta$-cells to GPR119 ligands also elicits a rise in cAMP; as does treatment of the intestinal Lcell line, GLUTag [105]. Thus, it can be concluded that GPR119 is predominantly coupled to Gs and that activation of the receptor promotes a rise in intracellular cAMP. This then accounts for the ability of GPR119 agonists to enhance glucose-dependent insulin secretion. 
In drawing this conclusion, it is worth noting that we have not been able to find any direct evidence in the literature showing that cAMP is elevated in primary islet cells upon activation of GPR119, although it seems reasonable to assume that this will be the case.

\section{Ligands of GPR119}

As outlined above, certain ethanolamide derivatives of long chain fatty acids have been shown to activate GPR119 and, among these, OEA is the most potent. In addition, steroyland palmitoyl-ethanolamide are also agonistic although the maximal response generated in a fluorescence-based assay in transfected yeast cells was lower with these ligands than with OEA [106]. Lysophospholipids may also be agonistic at GPR119 since a range of lysophosphatidycholine species having oleoly, steroyl or palmitoyl derivatives at the C-1 position were all able to raise cAMP in cells expressing GPR119; as were lysophosphatidylethanolamine and lysophosphatidylinositol [107]. It remains uncertain which (if any) of these can serve as a physiological ligand but OEA is a strong candidate since this molecule is produced in the intestine and may also be present in blood as well as, locally, within other tissues [108-111].

OEA is well-known to exert a powerful orexogenic effect in vivo and this has raised the possibility that it (or a suitable derivative) may be useful in the treatment of obesity. However, it is not entirely clear whether this activity is mediated via GPR119, since OEA can also activate certain vanilloid receptors (notably TRPV1) and PPAR- $\alpha$, either of which may mediate some of its actions [112]. Indeed, a recent study has revealed that, in mice deficient in GPR119, administration of OEA still exerts a powerful hypophagic response, suggesting that GPR119 is not absolutely required for this effect [113]. Nevertheless, GPR119 remains a potentially important pharmacological target for the improvement of glucose-induced insulin secretion in patients in whom this response is impaired.

In an attempt to move forward the development of pharmacological ligands targeted to GPR119, a number of groups have reported the synthesis of small molecules which can serve as agonists of this receptor [114-116]. These have largely been developed on the basis of their ability to elicit a response in cells transfected to express GPR119 but, encouragingly, several have also been shown to display activity in vivo. Among these, PSN632408, developed by Prosidion [117], causes a rise in cAMP and insulin secretion from HIT-T15 and MIN6 cells and also induces hypohagia in rats (although, as mentioned above, this latter response may not be completely dependent on GPR119). Interestingly, PSN632408 displays a bell-shaped dose response curve on insulin secretion (and cAMP accumulation) in MIN6 cells with concentrations in the low $\mu \mathrm{M}$ range causing a rise in 
secretion, while this effect is attenuated at higher doses [118]. The reasons for this have not been established.

A second low molecular weight GPR119 agonist, AR231453 (from Arena Pharmaceuticals) also promotes cAMP formation and insulin secretion from HIT-T15 cells and it improved glucose tolerance when given orally to a variety of animal models of type 2 diabetes [119]. There was a marked increase in glucose-induced insulin secretion in animals treated with AR231453 suggesting that the effects were a reflection of improved $\beta$-cell function. Importantly (and as expected for an agent acting primarily via the cAMP signalling system) even high doses of AR231453 did not elicit hypoglycaemia in experimental animals, consistent with a clear glucose-dependence for the insulin secretory response. Deletion of GPR119 abrogated the responses to AR231453. Interestingly, however, GPR119-deficient animals did not display abnormal glucose homeostasis per se when fed a standard laboratory diet, suggesting that the receptor is not absolutely required for normal glucose tolerance $[120 ; 121]$.

In addition to exerting effects on insulin secretion, it was shown recently that oral administration of AR231453 to mice induced a rapid release of GLP-1 from intestinal L-cells [122]. This implies that GPR119 is also expressed by certain cells of the small intestine and this conclusion has received direct support by analysis of mRNA extracted from L-cells [123]. Since GLP-1 can, in turn, stimulate insulin secretion, it is possible that, when administered by the oral route, GPR119 agonists may exert a bi-functional effect to promote insulin release, involving both direct (via $\beta$-cells) and indirect (via intestinal cells) actions. Indeed, recent studies have confirmed that GPR119 is expressed in both K- and L-cells of the small intestine and that it acts functionally to control GIP and GLP-1 secretion, respectively, from these cells [124;125]. Since GIP and GLP-1 can each promote insulin secretion by acting on the $\beta$-cell, this provides a means by which agonism of GPR119 in the intestine can elicit a secondary insulin secretory response.

\section{GPR120}

A third G-protein coupled fatty acid receptor that may play a role in controlling pancreatic $\beta$ cell function is GPR120. However, the idea that GPR120 is expressed in islet endocrine cells is still controversial since initial studies failed to detect GPR120 mRNA in MIN6 $\beta$-cells [126]. By contrast, we find that the mRNA encoding GPR120 is readily detected in a range of rat $\beta$ cell lines (including INS-1 and BRIN-BD11) as well as in human islets (Dhayal \& Morgan; unpublished studies). It remains to be confirmed whether GPR120 protein is present in these 
cells but, currently, this objective is difficult to achieve due to the lack of readily available antisera with proven specificity.

The gene encoding GPR120 is located on chromosome 10q23.33 and may have up to 4 exons [127]. Analysis of GPR120 cDNA sequences deposited in public databases suggests that at least two different splice variant forms may exist; one being 377 amino acids in the length while the second is shorter, at 361 residues. We have recently analysed the expression of these two variants in rodent $\beta$-cells and in human islet cDNA and could find only the shorter form (which lacks a sequence encoding 16 amino acids between positions 231 and 247 of the putative longer variant). Thus, it seems likely that the shorter form of GPR120 is the major isoforms present in the endocrine pancreas. At present, it is unclear whether these two forms of GPR120 are differentially coupled to intracellular signalling systems and their respective roles remain to be established.

Even if it is confirmed that GPR120 is present in $\beta$-cells at the protein level, it can be deduced from previous work that this receptor probably plays a negligible role in regulation of insulin secretion mediated by fatty acids. This is because deletion of GPR40 leads to loss of the acute insulin secretory response to fatty acids in mouse islets [128] and siRNAmediated knockdown of GPR40 in MIN6 cells also results in loss of this response [129]. Since GPR120 should retain its expression and functionality under these conditions, the results imply that GPR120 cannot play a primary role in mediating the acute effects of fatty acids on insulin secretion. Furthermore, it is also evident that any effects of orally administered GPR120 agonists on insulin secretion are likely to be mediated mainly by indirect actions on the intestine. This is because GPR120 is expressed on intestinal enteroendocrine cells where it regulates the secretion of incretins such as GIP, GLP-1 and cholecystokinin [130-134]. Therefore, on the basis of these considerations, it seems unlikely that GPR120 plays any direct role in regulating insulin secretion.

The ligand specificity of GPR120 has been determined in a variety of functional analyses and it is clear that the receptor has a relatively wide specificity [135]. GPR120 is sometimes cited as an "unsaturated fatty acid receptor" but the available evidence suggests that this is an over-simplification. Rather, GPR120 can be activated by various saturated free fatty acids ranging in chain length from $\mathrm{C} 14$ to $\mathrm{C} 18$, as well as by both mono- and poly-unsaturated free fatty acids with chain lengths of between 16 to 22 carbon atoms [136]. Thus, it appears to display a considerable tolerance in the structural features required for ligand binding. In this context, it has been noted that the methyl-esters of long chain polyunsaturated fatty acids are inactive suggesting that, as in the case of GPR40, the presence of a free carboxylate group may be important for correct orientation of the ligand within the binding site [137]. 
Despite this, there is no obvious structural homology which might suggest that ligand binding to GPR40 and GPR120 involves equivalent amino acid residues.

Functionally, there is a consensus that GPR120 elicits a rise in cytosolic free $\mathrm{Ca}$ in cells suggesting that, similarly to GPR40, it is coupled primarily to Gq [138;139]. It can also induce the activation of extracellular signal-regulated kinases (ERK) under certain conditions [140;141] but it is unclear whether this response derives from the rise in cytosolic Ca or whether an independent coupling mechanism is involved. Activation of PI-3-kinase and of the serine/threonine protein kinase Akt, have also been seen in GPR120-expressing cells [142].

The functional role of GPR120 in the pancreatic $\beta$-cell remains to be established but consideration of its proposed mechanism of action in the STC-1 line of intestinal cells may be instructive. In these cells, long chain unsaturated free fatty acids are cytoprotective [143] and the mechanisms appear to involve GPR120 since knockdown of this receptor leads to attenuation of the cytoprotective response. Examination of the signalling mechanisms suggests that activation of both ERK and the PI-3-kinase/Akt pathways may be required and that these culminate in a reduction in the activity of the pro-apoptotic effector enzyme, caspase 3 . Since unsaturated fatty acids can exert a similar cytoprotective action in the pancreatic $\beta$-cell [144;145], it is tempting to speculate that GPR120 might be implicated in mediating this response too. However, firm evidence to support this hypothesis is entirely lacking. Indeed, the demonstration that methyl-esters of unsaturated fatty acids are extremely potent cytoprotective agents in the $\beta$-cell [146] argues against this possibility since these fatty acids do not activate GPR120. Thus, at present its role in $\beta$-cells remains enigmatic.

\section{Conclusions and perspectives}

It is abundantly clear from recent studies that the actions of fatty acids in beta-cells are both metabolic and "hormonal". Mounting evidence suggests that the latter derive, in large part, from the binding of the molecules to cell surface receptors belonging to the family of 7 transmembrane domain, G-protein coupled receptors. Among these, GPR40 is likely to mediate many of the acute stimulatory effects of long chain fatty acids on insulin secretion (via activation of $\mathrm{Gq}$ and Ca signalling) and GPR119 probably plays a similar role (mediated by increased CAMP) in response to ethanolamide fatty acid derivatives and certain lysophospholipids. GPR120 is also expressed in beta-cells but plays, at best, only a limited role in the regulation of insulin secretion. Its primary function has still to be defined. None of 
these fatty acid receptors has been shown unequivocally to mediate the chronic lipotoxic actions of fatty acids in beta-cells although a cytoprotective role for GPR120 cannot be excluded. Accumulating evidence suggests that small molecule ligands (which are not fatty acids) can be identified for these receptors and it is likely that such molecules will prove useful as therapeutic agents to promote insulin secretion in patients with type 2 diabetes in future.

\section{Acknowledgements}

Work on $\beta$-cell fatty acid responses performed in the authors' laboratory has been generously supported by European Foundation for the Study of Diabetes, BBSRC, GlaxoSmithKline, Servier, Boehringer-Ingelheim, and AstraZeneca. 
Figure 1. Signalling mechanisms mediated by GPR40 in pancreatic $\boldsymbol{\beta}$-cells. Long chain saturated and mono- or poly-unsaturated fatty acids bind to GPR40 which then couples to the G-protein Gq. This leads to increased phospholipase C (PLC) activity leading to the hydrolysis of plasma membrane phosphatidylinositol-4,5 bisphosphate $\left(\mathrm{PIP}_{2}\right)$ and the consequent generation of inositol 1,4,5 trisphosphate $\left(\mathrm{IP}_{3}\right)$ and diacylglycerol (DAG). The latter can activate protein kinase $C(P K C)$ to potentiate insulin secretion while the former diffuses to the endoplasmic reticulum causing the release of stored $\mathrm{Ca}^{2+}$. Activation of GPR40 also leads to inhibition of the opening of voltage-gated potassium channels thereby promoting enhanced membrane depolarisation and net $\mathrm{Ca}^{2+}$ influx via L-type $\mathrm{Ca}^{2+}$ channels.

Figure 2. Putative topology of human GPR40 with the amino acid sequence shown in single letter code. GPR40 has the classical 7-transmembrane domain structure found in all G-protein coupled receptors. The N-terminus is external to the cell and the C-terminus resides in the cytosol. The putative transmembrane domains are shown in brown. Residues indicated in blue ( $\operatorname{Arg}^{183}, \mathrm{Asn}^{244}$ and $\mathrm{Arg}^{258}$ ) are thought to be involved in coordination of the carboxyl group of fatty acids during ligand binding. In the absence of ligand, $\operatorname{Arg}^{183}$ and $\operatorname{Arg}^{258}$ form an ionic lock with two glutamate residues ( $\mathrm{Glu}^{145}$ and $\mathrm{Glu}^{172}$; shown in red) located in the second extracellular loop. This stabilises the inactive conformation of the receptor. The ionic lock is broken during ligand binding to allow receptor activation. Two further residues (Gly ${ }^{180}$ and $\mathrm{Arg}^{211}$; shown in purple) are encoded within regions showing common variation (single nucleotide polymorphisms) which may influence receptor functionality. 
Reference List

(1) Prentki M, Tornheim K, Corkey BE: Signal transduction mechanisms in nutrientinduced insulin secretion. Diabetologia 1997; 40 Suppl 2:S32-S41.

(2) Turk J, Gross RW, Ramanadham S: Amplification of insulin secretion by lipid messengers. Diabetes 1993; 42(3):367-374.

(3) Eizirik DL, Cardozo AK, Cnop M: The role for endoplasmic reticulum stress in diabetes mellitus. Endocr Rev 2008; 29(1):42-61.

(4) Morgan NG: Fatty acids and beta-cell toxicity. Curr Opin Clin Nutr Metab Care 2009; 12(2):117-122.

(5) Eizirik DL, Cardozo AK, Cnop M: The role for endoplasmic reticulum stress in diabetes mellitus. Endocr Rev 2008; 29(1):42-61.

(6) Morgan NG: Fatty acids and beta-cell toxicity. Curr Opin Clin Nutr Metab Care 2009; 12(2):117-122.

(7) Poitout V, Robertson RP: Glucolipotoxicity: fuel excess and beta-cell dysfunction. Endocr Rev 2008; 29(3):351-366.

(8) Covington DK, Briscoe CA, Brown AJ, Jayawickreme CK: The G-protein-coupled receptor 40 family (GPR40-GPR43) and its role in nutrient sensing. Biochem Soc Trans 2006; 34(Pt 5):770-773.

(9) Rayasam GV, Tulasi VK, Davis JA, Bansal VS: Fatty acid receptors as new therapeutic targets for diabetes. Expert Opin Ther Targets 2007; 11(5):661-671.

(10) Stoddart LA, Smith NJ, Milligan G: International Union of Pharmacology. LXXI. Free fatty acid receptors FFA1, -2 , and -3 : pharmacology and pathophysiological functions. Pharmacol Rev 2008; 60(4):405-417.

(11) Swaminath G: Fatty acid binding receptors and their physiological role in type 2 diabetes. Arch Pharm (Weinheim) 2008; 341(12):753-761.

(12) Hirasawa A, Hara T, Katsuma S, Adachi T, Tsujimoto G: Free fatty acid receptors and drug discovery. Biol Pharm Bull 2008; 31(10):1847-1851.

(13) Wellendorph $\mathrm{P}$, Johansen LD, Brauner-Osborne H: Molecular pharmacology of promiscuous 7TM receptors sensing organic nutrients. Mol Pharmacol 2009.

(14) Sugden MC, Holness MJ: Role of nuclear receptors in the modulation of insulin secretion in lipid-induced insulin resistance. Biochem Soc Trans 2008; 36(Pt 5):891900. 
(15) Sawzdargo M, George SR, Nguyen T, Xu S, Kolakowski LF, O'Dowd BF: A cluster of four novel human $G$ protein-coupled receptor genes occurring in close proximity to CD22 gene on chromosome 19q13.1. Biochem Biophys Res Commun 1997; 239(2):543-547.

(16) Stoddart LA, Smith NJ, Milligan G: International Union of Pharmacology. LXXI. Free fatty acid receptors FFA1, -2 , and -3 : pharmacology and pathophysiological functions. Pharmacol Rev 2008; 60(4):405-417.

(17) Brown AJ, Goldsworthy SM, Barnes AA, Eilert MM, Tcheang L, Daniels D, Muir AI, Wigglesworth MJ, Kinghorn I, Fraser NJ, Pike NB, Strum JC, Steplewski KM, Murdock PR, Holder JC, Marshall FH, Szekeres PG, Wilson S, Ignar DM, Foord SM, Wise A, Dowell SJ: The Orphan G protein-coupled receptors GPR41 and GPR43 are activated by propionate and other short chain carboxylic acids. J Biol Chem 2003; 278(13):11312-11319.

(18) Nilsson NE, Kotarsky K, Owman C, Olde B: Identification of a free fatty acid receptor, FFA2R, expressed on leukocytes and activated by short-chain fatty acids. Biochem Biophys Res Commun 2003; 303(4):1047-1052.

(19) Gotoh C, Hong YH, Iga T, Hishikawa D, Suzuki Y, Song SH, Choi KC, Adachi T, Hirasawa A, Tsujimoto G, Sasaki S, Roh SG: The regulation of adipogenesis through GPR120. Biochem Biophys Res Commun 2007; 354(2):591-597.

(20) Tanaka T, Yano T, Adachi T, Koshimizu TA, Hirasawa A, Tsujimoto G: Cloning and characterization of the rat free fatty acid receptor GPR120: in vivo effect of the natural ligand on GLP-1 secretion and proliferation of pancreatic beta cells. Naunyn Schmiedebergs Arch Pharmacol 2008; 377(4-6):515-522.

(21) Fredriksson R, Hoglund PJ, Gloriam DE, Lagerstrom MC, Schioth HB: Seven evolutionarily conserved human rhodopsin $\mathrm{G}$ protein-coupled receptors lacking close relatives. FEBS Lett 2003; 554(3):381-388.

(22) Wang D, Wei Y, Pagliassotti MJ: Saturated fatty acids promote endoplasmic reticulum stress and liver injury in rats with hepatic steatosis. Endocrinology 2006; 147(2):943-951.

(23) Steneberg P, Rubins N, Bartoov-Shifman R, Walker MD, Edlund H: The FFA receptor GPR40 links hyperinsulinemia, hepatic steatosis, and impaired glucose homeostasis in mouse. Cell Metab 2005; 1(4):245-258.

(24) Itoh Y, Hinuma S: GPR40, a free fatty acid receptor on pancreatic beta cells, regulates insulin secretion. Hepatol Res 2005; 33(2):171-173.

(25) Tomita T, Masuzaki H, Noguchi M, Iwakura H, Fujikura J, Tanaka T, Ebihara K, Kawamura J, Komoto I, Kawaguchi Y, Fujimoto K, Doi R, Shimada Y, Hosoda K, Imamura M, Nakao K: GPR40 gene expression in human pancreas and insulinoma. Biochem Biophys Res Commun 2005; 338(4):1788-1790.

(26) Hirasawa A, Itsubo C, Sadakane K, Hara T, Shinagawa S, Koga H, Nose H, Koshimizu TA, Tsujimoto G: Production and characterization of a monoclonal antibody against GPR40 (FFAR1; free fatty acid receptor 1). Biochem Biophys Res Commun 2008; 365(1):22-28. 
(27) Itoh Y, Kawamata Y, Harada M, Kobayashi M, Fujii R, Fukusumi S, Ogi K, Hosoya M, Tanaka Y, Uejima H, Tanaka H, Maruyama M, Satoh R, Okubo S, Kizawa H, Komatsu H, Matsumura F, Noguchi Y, Shinohara T, Hinuma S, Fujisawa Y, Fujino M: Free fatty acids regulate insulin secretion from pancreatic beta cells through GPR40. Nature 2003; 422(6928):173-176.

(28) Flodgren E, Olde B, Meidute-Abaraviciene S, Winzell MS, Ahren B, Salehi A: GPR40 is expressed in glucagon producing cells and affects glucagon secretion. Biochem Biophys Res Commun 2007; 354(1):240-245.

(29) Bartoov-Shifman R, Ridner G, Bahar K, Rubins N, Walker MD: Regulation of the gene encoding GPR40, a fatty acid receptor expressed selectively in pancreatic beta cells. J Biol Chem 2007; 282(32):23561-23571.

(30) Ridner G, Bartoov-Shifman R, Zalogin T, vnit-Sagi T, Bahar K, Sharivkin R, Kantorovich L, Weiss S, Walker MD: Regulation of the GPR40 locus: towards a molecular understanding. Biochem Soc Trans 2008; 36(Pt 3):360-362.

(31) Bartoov-Shifman R, Ridner G, Bahar K, Rubins N, Walker MD: Regulation of the gene encoding GPR40, a fatty acid receptor expressed selectively in pancreatic beta cells. J Biol Chem 2007; 282(32):23561-23571.

(32) Parker HE, Habib AM, Rogers GJ, Gribble FM, Reimann F: Nutrient-dependent secretion of glucose-dependent insulinotropic polypeptide from primary murine $\mathrm{K}$ cells. Diabetologia 2009; 52(2):289-298.

(33) Edfalk S, Steneberg P, Edlund H: Gpr40 is expressed in enteroendocrine cells and mediates free fatty acid stimulation of incretin secretion. Diabetes 2008; 57(9):22802287.

(34) Itoh Y, Kawamata Y, Harada M, Kobayashi M, Fujii R, Fukusumi S, Ogi K, Hosoya M, Tanaka Y, Uejima H, Tanaka H, Maruyama M, Satoh R, Okubo S, Kizawa H, Komatsu H, Matsumura F, Noguchi Y, Shinohara T, Hinuma S, Fujisawa Y, Fujino M: Free fatty acids regulate insulin secretion from pancreatic beta cells through GPR40. Nature 2003; 422(6928):173-176.

(35) Schnell S, Schaefer M, Schofl C: Free fatty acids increase cytosolic free calcium and stimulate insulin secretion from beta-cells through activation of GPR40. Mol Cell Endocrinol 2007; 263(1-2):173-180.

(36) Briscoe CP, Tadayyon M, Andrews JL, Benson WG, Chambers JK, Eilert MM, Ellis C, Elshourbagy NA, Goetz AS, Minnick DT, Murdock PR, Sauls HR, Jr., Shabon U, Spinage LD, Strum JC, Szekeres PG, Tan KB, Way JM, Ignar DM, Wilson S, Muir Al: The orphan $\mathrm{G}$ protein-coupled receptor GPR40 is activated by medium and long chain fatty acids. J Biol Chem 2003; 278(13):11303-11311.

(37) Itoh Y, Kawamata Y, Harada M, Kobayashi M, Fujii R, Fukusumi S, Ogi K, Hosoya M, Tanaka Y, Uejima H, Tanaka H, Maruyama M, Satoh R, Okubo S, Kizawa H, Komatsu H, Matsumura F, Noguchi Y, Shinohara T, Hinuma S, Fujisawa Y, Fujino M: Free fatty acids regulate insulin secretion from pancreatic beta cells through GPR40. Nature 2003; 422(6928):173-176.

(38) Sum CS, Tikhonova IG, Neumann S, Engel S, Raaka BM, Costanzi S, Gershengorn MC: Identification of residues important for agonist recognition and activation in GPR40. J Biol Chem 2007; 282(40):29248-29255. 
(39) Christiansen E, Urban C, Merten N, Liebscher K, Karlsen KK, Hamacher A, Spinrath A, Bond AD, Drewke C, Ullrich S, Kassack MU, Kostenis E, Ulven T: Discovery of potent and selective agonists for the free fatty acid receptor 1 (FFA(1)/GPR40), a potential target for the treatment of type II diabetes. J Med Chem 2008; 51(22):70617064.

(40) Sum CS, Tikhonova IG, Costanzi S, Gershengorn MC: Two arginine-glutamate ionic locks near the extracellular surface of FFAR1 gate receptor activation. J Biol Chem 2009; 284(6):3529-3536.

(41) Kotarsky K, Nilsson NE, Flodgren E, Owman C, Olde B: A human cell surface receptor activated by free fatty acids and thiazolidinedione drugs. Biochem Biophys Res Commun 2003; 301(2):406-410.

(42) Gras D, Chanez P, Urbach V, Vachier I, Godard P, Bonnans C: Thiazolidinediones induce proliferation of human bronchial epithelial cells through the GPR40 receptor. Am J Physiol Lung Cell Mol Physiol 2009; 296(6):L970-L978.

(43) Tan CP, Feng Y, Zhou YP, Eiermann GJ, Petrov A, Zhou C, Lin S, Salituro G, Meinke P, Mosley R, Akiyama TE, Einstein M, Kumar S, Berger JP, Mills SG, Thornberry NA, Yang L, Howard AD: Selective Small-Molecule Agonists of G proteincoupled Receptor 40 Promote Glucose-Dependent Insulin Secretion and Reduce Blood Glucose in Mice. Diabetes 2008.

(44) Tan CP, Feng Y, Zhou YP, Eiermann GJ, Petrov A, Zhou C, Lin S, Salituro G, Meinke P, Mosley R, Akiyama TE, Einstein M, Kumar S, Berger JP, Mills SG, Thornberry NA, Yang L, Howard AD: Selective Small-Molecule Agonists of G proteincoupled Receptor 40 Promote Glucose-Dependent Insulin Secretion and Reduce Blood Glucose in Mice. Diabetes 2008.

(45) Itoh Y, Kawamata Y, Harada M, Kobayashi M, Fujii R, Fukusumi S, Ogi K, Hosoya M, Tanaka Y, Uejima H, Tanaka H, Maruyama M, Satoh R, Okubo S, Kizawa H, Komatsu H, Matsumura F, Noguchi Y, Shinohara T, Hinuma S, Fujisawa Y, Fujino M: Free fatty acids regulate insulin secretion from pancreatic beta cells through GPR40. Nature 2003; 422(6928):173-176.

(46) Briscoe CP, Tadayyon M, Andrews JL, Benson WG, Chambers JK, Eilert MM, Ellis C, Elshourbagy NA, Goetz AS, Minnick DT, Murdock PR, Sauls HR, Jr., Shabon U, Spinage LD, Strum JC, Szekeres PG, Tan KB, Way JM, Ignar DM, Wilson S, Muir Al: The orphan $\mathrm{G}$ protein-coupled receptor GPR40 is activated by medium and long chain fatty acids. J Biol Chem 2003; 278(13):11303-11311.

(47) Shapiro H, Shachar S, Sekler I, Hershfinkel M, Walker MD: Role of GPR40 in fatty acid action on the beta cell line INS-1E. Biochem Biophys Res Commun 2005; 335(1):97-104.

(48) Hara T, Hirasawa A, Sun Q, Koshimizu TA, Itsubo C, Sadakane K, Awaji T, Tsujimoto G: Flow cytometry-based binding assay for GPR40 (FFAR1; free fatty acid receptor 1). Mol Pharmacol 2009; 75(1):85-91.

(49) Fujiwara K, Maekawa F, Yada T: Oleic acid interacts with GPR40 to induce Ca2+ signaling in rat islet beta-cells: mediation by PLC and L-type Ca2+ channel and link to insulin release. Am J Physiol Endocrinol Metab 2005; 289(4):E670-E677. 
(50) Briscoe CP, Tadayyon M, Andrews JL, Benson WG, Chambers JK, Eilert MM, Ellis C, Elshourbagy NA, Goetz AS, Minnick DT, Murdock PR, Sauls HR, Jr., Shabon U, Spinage LD, Strum JC, Szekeres PG, Tan KB, Way JM, Ignar DM, Wilson S, Muir Al: The orphan $\mathrm{G}$ protein-coupled receptor GPR40 is activated by medium and long chain fatty acids. J Biol Chem 2003; 278(13):11303-11311.

(51) Salehi A, Flodgren E, Nilsson NE, Jimenez-Feltstrom J, Miyazaki J, Owman C, Olde B: Free fatty acid receptor 1 (FFA(1)R/GPR40) and its involvement in fatty-acidstimulated insulin secretion. Cell Tissue Res 2005; 322(2):207-215.

(52) Shapiro H, Shachar S, Sekler I, Hershfinkel M, Walker MD: Role of GPR40 in fatty acid action on the beta cell line INS-1E. Biochem Biophys Res Commun 2005; 335(1):97-104.

(53) Latour MG, Alquier T, Oseid E, Tremblay C, Jetton TL, Luo J, Lin DC, Poitout V: GPR40 is necessary but not sufficient for fatty acid stimulation of insulin secretion in vivo. Diabetes 2007; 56(4):1087-1094.

(54) Itoh Y, Kawamata Y, Harada M, Kobayashi M, Fujii R, Fukusumi S, Ogi K, Hosoya M, Tanaka Y, Uejima H, Tanaka H, Maruyama M, Satoh R, Okubo S, Kizawa H, Komatsu H, Matsumura F, Noguchi Y, Shinohara T, Hinuma S, Fujisawa Y, Fujino M: Free fatty acids regulate insulin secretion from pancreatic beta cells through GPR40. Nature 2003; 422(6928):173-176.

(55) Feng DD, Luo Z, Roh SG, Hernandez M, Tawadros N, Keating DJ, Chen C: Reduction in voltage-gated $\mathrm{K}+$ currents in primary cultured rat pancreatic beta-cells by linoleic acids. Endocrinology 2006; 147(2):674-682.

(56) Gwiazda KS, Yang TL, Lin Y, Johnson JD: Effects of palmitate on ER and cytosolic Ca2+ homeostasis in beta-cells. Am J Physiol Endocrinol Metab 2009; 296(4):E690E701.

(57) Feng DD, Luo Z, Roh SG, Hernandez M, Tawadros N, Keating DJ, Chen C: Reduction in voltage-gated $\mathrm{K}+$ currents in primary cultured rat pancreatic beta-cells by linoleic acids. Endocrinology 2006; 147(2):674-682.

(58) Feng DD, Luo Z, Roh SG, Hernandez M, Tawadros N, Keating DJ, Chen C: Reduction in voltage-gated $\mathrm{K}+$ currents in primary cultured rat pancreatic beta-cells by linoleic acids. Endocrinology 2006; 147(2):674-682.

(59) Welters HJ, Diakogiannaki E, Mordue JM, Tadayyon M, Smith SA, Morgan NG: Differential protective effects of palmitoleic acid and cAMP on caspase activation and cell viability in pancreatic beta-cells exposed to palmitate. Apoptosis 2006; 11(7):1231-1238.

(60) Ogawa T, Hirose H, Miyashita K, Saito I, Saruta T: GPR40 gene Arg211His polymorphism may contribute to the variation of insulin secretory capacity in Japanese men. Metabolism 2005; 54(3):296-299.

(61) Vettor R, Granzotto M, De SD, Trevellin E, Rossato M, Farina MG, Milan G, Pilon C, Nigro A, Federspil G, Vigneri R, Vitiello L, Rizzuto R, Baratta R, Frittitta L: Loss-offunction mutation of the GPR40 gene associates with abnormal stimulated insulin secretion by acting on intracellular calcium mobilization. J Clin Endocrinol Metab 2008; 93(9):3541-3550. 
(62) Ogawa T, Hirose H, Miyashita K, Saito I, Saruta T: GPR40 gene Arg211His polymorphism may contribute to the variation of insulin secretory capacity in Japanese men. Metabolism 2005; 54(3):296-299.

(63) Vettor R, Granzotto M, De SD, Trevellin E, Rossato M, Farina MG, Milan G, Pilon C, Nigro A, Federspil G, Vigneri R, Vitiello L, Rizzuto R, Baratta R, Frittitta L: Loss-offunction mutation of the GPR40 gene associates with abnormal stimulated insulin secretion by acting on intracellular calcium mobilization. J Clin Endocrinol Metab 2008; 93(9):3541-3550.

(64) Steneberg P, Rubins N, Bartoov-Shifman R, Walker MD, Edlund H: The FFA receptor GPR40 links hyperinsulinemia, hepatic steatosis, and impaired glucose homeostasis in mouse. Cell Metab 2005; 1(4):245-258.

(65) Humphries PS, Benbow JW, Bonin PD, Boyer D, Doran SD, Frisbie RK, Piotrowski DW, Balan G, Bechle BM, Conn EL, Dirico KJ, Oliver RM, Soeller WC, Southers JA, Yang X: Synthesis and SAR of 1,2,3,4-tetrahydroisoquinolin-1-ones as novel Gprotein-coupled receptor 40 (GPR40) antagonists. Bioorg Med Chem Lett 2009; 19(9):2400-2403.

(66) Steneberg P, Rubins N, Bartoov-Shifman R, Walker MD, Edlund H: The FFA receptor GPR40 links hyperinsulinemia, hepatic steatosis, and impaired glucose homeostasis in mouse. Cell Metab 2005; 1(4):245-258.

(67) Kebede M, Alquier T, Latour MG, Semache M, Tremblay C, Poitout V: The fatty acid receptor GPR40 plays a role in insulin secretion in vivo after high-fat feeding. Diabetes 2008; 57(9):2432-2437.

(68) Lan H, Hoos LM, Liu L, Tetzloff G, Hu W, Abbondanzo SJ, Vassileva G, Gustafson EL, Hedrick JA, Davis HR: Lack of FFAR1/GPR40 does not protect mice from highfat diet-induced metabolic disease. Diabetes 2008; 57(11):2999-3006.

(69) Brownlie R, Mayers RM, Pierce JA, Marley AE, Smith DM: The long-chain fatty acid receptor, GPR40, and glucolipotoxicity: investigations using GPR40-knockout mice. Biochem Soc Trans 2008; 36(Pt 5):950-954.

(70) Nagasumi K, Esaki R, Iwachidow K, Yasuhara Y, Ogi K, Tanaka H, Nakata M, Yano T, Shimakawa K, Taketomi S, Takeuchi K, Odaka H, Kaisho Y: Overexpression of GPR40 in pancreatic beta-cells augments glucose-stimulated insulin secretion and improves glucose tolerance in normal and diabetic mice. Diabetes 2009; 58(5):10671076.

(71) Doshi LS, Brahma MK, Sayyed SG, Dixit AV, Chandak PG, Pamidiboina V, Motiwala $\mathrm{HF}$, Sharma SD, Nemmani KV: Acute administration of GPR40 receptor agonist potentiates glucose-stimulated insulin secretion in vivo in the rat. Metabolism 2009; 58(3):333-343.

(72) Dhayal S, Welters HJ, Morgan NG: Structural requirements for the cytoprotective actions of mono-unsaturated fatty acids in the pancreatic beta-cell line, BRIN-BD11. Br J Pharmacol 2008; 153(8):1718-1727.

(73) Morgan NG, Dhayal S, Diakogiannaki E, Welters HJ: The cytoprotective actions of long-chain mono-unsaturated fatty acids in pancreatic beta-cells. Biochem Soc Trans 2008; 36(Pt 5):905-908. 
(74) Zhang Y, Xu M, Zhang S, Yan L, Yang C, Lu W, Li Y, Cheng H: The role of G protein-coupled receptor 40 in lipoapoptosis in mouse beta-cell line NIT-1. J Mol Endocrinol 2007; 38(6):651-661.

(75) Morgan NG, Dhayal S, Diakogiannaki E, Welters HJ: The cytoprotective actions of long-chain mono-unsaturated fatty acids in pancreatic beta-cells. Biochem Soc Trans 2008; 36(Pt 5):905-908.

(76) Dhayal S, Welters HJ, Morgan NG: Structural requirements for the cytoprotective actions of mono-unsaturated fatty acids in the pancreatic beta-cell line, BRIN-BD11. Br J Pharmacol 2008; 153(8):1718-1727.

(77) Soga T, Ohishi T, Matsui T, Saito T, Matsumoto M, Takasaki J, Matsumoto S, Kamohara M, Hiyama H, Yoshida S, Momose K, Ueda Y, Matsushime H, Kobori M, Furuichi K: Lysophosphatidylcholine enhances glucose-dependent insulin secretion via an orphan G-protein-coupled receptor. Biochem Biophys Res Commun 2005; 326(4):744-751.

(78) Overton HA, Babbs AJ, Doel SM, Fyfe MC, Gardner LS, Griffin G, Jackson HC, Procter MJ, Rasamison CM, Tang-Christensen M, Widdowson PS, Williams GM, Reynet C: Deorphanization of a G protein-coupled receptor for oleoylethanolamide and its use in the discovery of small-molecule hypophagic agents. Cell Metab 2006; 3(3):167-175.

(79) Fredriksson R, Hoglund PJ, Gloriam DE, Lagerstrom MC, Schioth HB: Seven evolutionarily conserved human rhodopsin $\mathrm{G}$ protein-coupled receptors lacking close relatives. FEBS Lett 2003; 554(3):381-388.

(80) Brown AJ: Novel cannabinoid receptors. Br J Pharmacol 2007; 152(5):567-575.

(81) Overton HA, Babbs AJ, Doel SM, Fyfe MC, Gardner LS, Griffin G, Jackson HC, Procter MJ, Rasamison CM, Tang-Christensen M, Widdowson PS, Williams GM, Reynet C: Deorphanization of a G protein-coupled receptor for oleoylethanolamide and its use in the discovery of small-molecule hypophagic agents. Cell Metab 2006; 3(3):167-175.

(82) Matias I, Gonthier MP, Petrosino S, Docimo L, Capasso R, Hoareau L, Monteleone $\mathrm{P}$, Roche R, Izzo AA, Di M, V: Role and regulation of acylethanolamides in energy balance: focus on adipocytes and beta-cells. Br J Pharmacol 2007; 152(5):676-690.

(83) Lambert DM, Muccioli GG: Endocannabinoids and related $\mathrm{N}$-acylethanolamines in the control of appetite and energy metabolism: emergence of new molecular players. Curr Opin Clin Nutr Metab Care 2007; 10(6):735-744.

(84) Hansen HS, Diep TA: N-acylethanolamines, anandamide and food intake. Biochem Pharmacol 2009.

(85) Overton HA, Babbs AJ, Doel SM, Fyfe MC, Gardner LS, Griffin G, Jackson HC, Procter MJ, Rasamison CM, Tang-Christensen M, Widdowson PS, Williams GM, Reynet C: Deorphanization of a G protein-coupled receptor for oleoylethanolamide and its use in the discovery of small-molecule hypophagic agents. Cell Metab 2006; 3(3):167-175. 
(86) Overton HA, Fyfe MC, Reynet C: GPR119, a novel G protein-coupled receptor target for the treatment of type 2 diabetes and obesity. Br J Pharmacol 2008; 153 Suppl 1:S76-S81.

(87) Sakamoto $\mathrm{Y}$, Inoue H, Kawakami S, Miyawaki K, Miyamoto T, Mizuta K, Itakura M: Expression and distribution of Gpr119 in the pancreatic islets of mice and rats: predominant localization in pancreatic polypeptide-secreting PP-cells. Biochem Biophys Res Commun 2006; 351(2):474-480.

(88) Chu ZL, Jones RM, He H, Carroll C, Gutierrez V, Lucman A, Moloney M, Gao H, Mondala H, Bagnol D, Unett D, Liang Y, Demarest K, Semple G, Behan DP, Leonard $\mathrm{J}$ : A role for beta-cell-expressed $\mathrm{G}$ protein-coupled receptor 119 in glycemic control by enhancing glucose-dependent insulin release. Endocrinology 2007; 148(6):26012609.

(89) Chu ZL, Carroll C, Alfonso J, Gutierrez V, He H, Lucman A, Pedraza M, Mondala H, Gao H, Bagnol D, Chen R, Jones RM, Behan DP, Leonard J: A role for intestinal endocrine cell-expressed g protein-coupled receptor 119 in glycemic control by enhancing glucagon-like Peptide-1 and glucose-dependent insulinotropic Peptide release. Endocrinology 2008; 149(5):2038-2047.

(90) Lauffer LM, lakoubov R, Brubaker PL: GPR119 is essential for oleoylethanolamideinduced glucagon-like peptide-1 secretion from the intestinal enteroendocrine L-cell. Diabetes 2009; 58(5):1058-1066.

(91) Lan H, Vassileva G, Corona A, Liu L, Baker H, Golovko A, Abbondanzo SJ, Hu W, Yang S, Ning Y, Del Vecchio RA, Poulet F, Laverty M, Gustafson EL, Hedrick JA, Kowalski TJ: GPR119 is required for physiological regulation of glucagon-like peptide-1 secretion but not for metabolic homeostasis. J Endocrinol 2009; 201(2):219-230.

(92) Parker HE, Habib AM, Rogers GJ, Gribble FM, Reimann F: Nutrient-dependent secretion of glucose-dependent insulinotropic polypeptide from primary murine $\mathrm{K}$ cells. Diabetologia 2009; 52(2):289-298.

(93) Overton HA, Fyfe MC, Reynet C: GPR119, a novel G protein-coupled receptor target for the treatment of type 2 diabetes and obesity. Br J Pharmacol 2008; 153 Suppl 1:S76-S81.

(94) Sakamoto Y, Inoue H, Kawakami S, Miyawaki K, Miyamoto T, Mizuta K, Itakura M: Expression and distribution of Gpr119 in the pancreatic islets of mice and rats: predominant localization in pancreatic polypeptide-secreting PP-cells. Biochem Biophys Res Commun 2006; 351(2):474-480.

(95) Soga T, Ohishi T, Matsui T, Saito T, Matsumoto M, Takasaki J, Matsumoto S, Kamohara M, Hiyama H, Yoshida S, Momose K, Ueda Y, Matsushime H, Kobori M, Furuichi K: Lysophosphatidylcholine enhances glucose-dependent insulin secretion via an orphan G-protein-coupled receptor. Biochem Biophys Res Commun 2005; 326(4):744-751.

(96) Chu ZL, Jones RM, He H, Carroll C, Gutierrez V, Lucman A, Moloney M, Gao H, Mondala H, Bagnol D, Unett D, Liang Y, Demarest K, Semple G, Behan DP, Leonard $\mathrm{J}$ : A role for beta-cell-expressed $\mathrm{G}$ protein-coupled receptor 119 in glycemic control by enhancing glucose-dependent insulin release. Endocrinology 2007; 148(6):26012609. 
(97) Chu ZL, Jones RM, He H, Carroll C, Gutierrez V, Lucman A, Moloney M, Gao H, Mondala H, Bagnol D, Unett D, Liang Y, Demarest K, Semple G, Behan DP, Leonard $\mathrm{J}$ : A role for beta-cell-expressed $\mathrm{G}$ protein-coupled receptor 119 in glycemic control by enhancing glucose-dependent insulin release. Endocrinology 2007; 148(6):26012609.

(98) Ning Y, O'Neill K, Lan H, Pang L, Shan LX, Hawes BE, Hedrick JA: Endogenous and synthetic agonists of GPR119 differ in signalling pathways and their effects on insulin secretion in MIN6c4 insulinoma cells. Br J Pharmacol 2008; 155(7):1056-1065.

(99) Chu ZL, Jones RM, He H, Carroll C, Gutierrez V, Lucman A, Moloney M, Gao H, Mondala H, Bagnol D, Unett D, Liang Y, Demarest K, Semple G, Behan DP, Leonard $\mathrm{J}$ : A role for beta-cell-expressed $\mathrm{G}$ protein-coupled receptor 119 in glycemic control by enhancing glucose-dependent insulin release. Endocrinology 2007; 148(6):26012609.

(100) Sakamoto Y, Inoue H, Kawakami S, Miyawaki K, Miyamoto T, Mizuta K, Itakura M: Expression and distribution of Gpr119 in the pancreatic islets of mice and rats: predominant localization in pancreatic polypeptide-secreting PP-cells. Biochem Biophys Res Commun 2006; 351(2):474-480.

(101) Soga T, Ohishi T, Matsui T, Saito T, Matsumoto M, Takasaki J, Matsumoto S, Kamohara M, Hiyama H, Yoshida S, Momose K, Ueda Y, Matsushime H, Kobori M, Furuichi K: Lysophosphatidylcholine enhances glucose-dependent insulin secretion via an orphan G-protein-coupled receptor. Biochem Biophys Res Commun 2005; 326(4):744-751.

(102) Chu ZL, Jones RM, He H, Carroll C, Gutierrez V, Lucman A, Moloney M, Gao H, Mondala H, Bagnol D, Unett D, Liang Y, Demarest K, Semple G, Behan DP, Leonard $\mathrm{J}$ : A role for beta-cell-expressed $\mathrm{G}$ protein-coupled receptor 119 in glycemic control by enhancing glucose-dependent insulin release. Endocrinology 2007; 148(6):26012609.

(103) Overton HA, Fyfe MC, Reynet C: GPR119, a novel G protein-coupled receptor target for the treatment of type 2 diabetes and obesity. Br J Pharmacol 2008; $153 \mathrm{Suppl}$ 1:S76-S81.

(104) Lauffer L, lakoubov R, Brubaker PL: GPR119: "double-dipping" for better glycemic control. Endocrinology 2008; 149(5):2035-2037.

(105) Chu ZL, Carroll C, Alfonso J, Gutierrez V, He H, Lucman A, Pedraza M, Mondala H, Gao H, Bagnol D, Chen R, Jones RM, Behan DP, Leonard J: A role for intestinal endocrine cell-expressed g protein-coupled receptor 119 in glycemic control by enhancing glucagon-like Peptide-1 and glucose-dependent insulinotropic Peptide release. Endocrinology 2008; 149(5):2038-2047.

(106) Overton HA, Babbs AJ, Doel SM, Fyfe MC, Gardner LS, Griffin G, Jackson HC, Procter MJ, Rasamison CM, Tang-Christensen M, Widdowson PS, Williams GM, Reynet C: Deorphanization of a G protein-coupled receptor for oleoylethanolamide and its use in the discovery of small-molecule hypophagic agents. Cell Metab 2006; 3(3):167-175.

(107) Soga T, Ohishi T, Matsui T, Saito T, Matsumoto M, Takasaki J, Matsumoto S, Kamohara M, Hiyama H, Yoshida S, Momose K, Ueda Y, Matsushime H, Kobori M, Furuichi K: Lysophosphatidylcholine enhances glucose-dependent insulin secretion 
via an orphan G-protein-coupled receptor. Biochem Biophys Res Commun 2005; 326(4):744-751.

(108) Schreiber D, Harlfinger S, Nolden BM, Gerth CW, Jaehde U, Schomig E, Klosterkotter J, Giuffrida A, Astarita G, Piomelli D, Markus LF: Determination of anandamide and other fatty acyl ethanolamides in human serum by electrospray tandem mass spectrometry. Anal Biochem 2007; 361(2):162-168.

(109) Fu J, Kim J, Oveisi F, Astarita G, Piomelli D: Targeted enhancement of oleoylethanolamide production in proximal small intestine induces across-meal satiety in rats. Am J Physiol Regul Integr Comp Physiol 2008; 295(1):R45-R50.

(110) Matias I, Gonthier MP, Petrosino S, Docimo L, Capasso R, Hoareau L, Monteleone $\mathrm{P}$, Roche R, Izzo AA, Di M, V: Role and regulation of acylethanolamides in energy balance: focus on adipocytes and beta-cells. Br J Pharmacol 2007; 152(5):676-690.

(111) Borrelli F, Izzo AA: Role of acylethanolamides in the gastrointestinal tract with special reference to food intake and energy balance. Best Pract Res Clin Endocrinol Metab 2009; 23(1):33-49.

(112) Borrelli F, Izzo AA: Role of acylethanolamides in the gastrointestinal tract with special reference to food intake and energy balance. Best Pract Res Clin Endocrinol Metab 2009; 23(1):33-49.

(113) Lan H, Vassileva G, Corona A, Liu L, Baker H, Golovko A, Abbondanzo SJ, Hu W, Yang S, Ning Y, Del Vecchio RA, Poulet F, Laverty M, Gustafson EL, Hedrick JA, Kowalski TJ: GPR119 is required for physiological regulation of glucagon-like peptide-1 secretion but not for metabolic homeostasis. J Endocrinol 2009; 201(2):219-230.

(114) Overton HA, Babbs AJ, Doel SM, Fyfe MC, Gardner LS, Griffin G, Jackson HC, Procter MJ, Rasamison CM, Tang-Christensen M, Widdowson PS, Williams GM, Reynet C: Deorphanization of a G protein-coupled receptor for oleoylethanolamide and its use in the discovery of small-molecule hypophagic agents. Cell Metab 2006; 3(3):167-175.

(115) Chu ZL, Jones RM, He H, Carroll C, Gutierrez V, Lucman A, Moloney M, Gao H, Mondala H, Bagnol D, Unett D, Liang Y, Demarest K, Semple G, Behan DP, Leonard $\mathrm{J}$ : A role for beta-cell-expressed $\mathrm{G}$ protein-coupled receptor 119 in glycemic control by enhancing glucose-dependent insulin release. Endocrinology 2007; 148(6):26012609.

(116) Semple G, Fioravanti B, Pereira G, Calderon I, Uy J, Choi K, Xiong Y, Ren A, Morgan M, Dave V, Thomsen W, Unett DJ, Xing C, Bossie S, Carroll C, Chu ZL, Grottick AJ, Hauser EK, Leonard J, Jones RM: Discovery of the first potent and orally efficacious agonist of the orphan G-protein coupled receptor 119. J Med Chem 2008; 51(17):5172-5175.

(117) Overton HA, Babbs AJ, Doel SM, Fyfe MC, Gardner LS, Griffin G, Jackson HC, Procter MJ, Rasamison CM, Tang-Christensen M, Widdowson PS, Williams GM, Reynet C: Deorphanization of a G protein-coupled receptor for oleoylethanolamide and its use in the discovery of small-molecule hypophagic agents. Cell Metab 2006; 3(3):167-175. 
(118) Ning Y, O'Neill K, Lan H, Pang L, Shan LX, Hawes BE, Hedrick JA: Endogenous and synthetic agonists of GPR119 differ in signalling pathways and their effects on insulin secretion in MIN6c4 insulinoma cells. Br J Pharmacol 2008; 155(7):1056-1065.

(119) Chu ZL, Jones RM, He H, Carroll C, Gutierrez V, Lucman A, Moloney M, Gao H, Mondala H, Bagnol D, Unett D, Liang Y, Demarest K, Semple G, Behan DP, Leonard $\mathrm{J}$ : A role for beta-cell-expressed $\mathrm{G}$ protein-coupled receptor 119 in glycemic control by enhancing glucose-dependent insulin release. Endocrinology 2007; 148(6):26012609.

(120) Chu ZL, Jones RM, He H, Carroll C, Gutierrez V, Lucman A, Moloney M, Gao H, Mondala H, Bagnol D, Unett D, Liang Y, Demarest K, Semple G, Behan DP, Leonard $\mathrm{J}$ : A role for beta-cell-expressed $\mathrm{G}$ protein-coupled receptor 119 in glycemic control by enhancing glucose-dependent insulin release. Endocrinology 2007; 148(6):26012609.

(121) Lan H, Vassileva G, Corona A, Liu L, Baker H, Golovko A, Abbondanzo SJ, Hu W, Yang S, Ning Y, Del Vecchio RA, Poulet F, Laverty M, Gustafson EL, Hedrick JA, Kowalski TJ: GPR119 is required for physiological regulation of glucagon-like peptide-1 secretion but not for metabolic homeostasis. J Endocrinol 2009; 201(2):219-230.

(122) Semple G, Fioravanti B, Pereira G, Calderon I, Uy J, Choi K, Xiong Y, Ren A, Morgan M, Dave V, Thomsen W, Unett DJ, Xing C, Bossie S, Carroll C, Chu ZL, Grottick AJ, Hauser EK, Leonard J, Jones RM: Discovery of the first potent and orally efficacious agonist of the orphan G-protein coupled receptor 119. J Med Chem 2008; 51(17):5172-5175.

(123) Lauffer LM, lakoubov R, Brubaker PL: GPR119 is essential for oleoylethanolamideinduced glucagon-like peptide-1 secretion from the intestinal enteroendocrine L-cell. Diabetes 2009; 58(5):1058-1066.

(124) Lauffer LM, lakoubov R, Brubaker PL: GPR119 is essential for oleoylethanolamideinduced glucagon-like peptide-1 secretion from the intestinal enteroendocrine L-cell. Diabetes 2009; 58(5):1058-1066.

(125) Parker HE, Habib AM, Rogers GJ, Gribble FM, Reimann F: Nutrient-dependent secretion of glucose-dependent insulinotropic polypeptide from primary murine $\mathrm{K}$ cells. Diabetologia 2009; 52(2):289-298.

(126) Hirasawa A, Tsumaya K, Awaji T, Katsuma S, Adachi T, Yamada M, Sugimoto Y, Miyazaki S, Tsujimoto G: Free fatty acids regulate gut incretin glucagon-like peptide1 secretion through GPR120. Nat Med 2005; 11(1):90-94.

(127) Fredriksson R, Hoglund PJ, Gloriam DE, Lagerstrom MC, Schioth HB: Seven evolutionarily conserved human rhodopsin $\mathrm{G}$ protein-coupled receptors lacking close relatives. FEBS Lett 2003; 554(3):381-388.

(128) Latour MG, Alquier T, Oseid E, Tremblay C, Jetton TL, Luo J, Lin DC, Poitout V: GPR40 is necessary but not sufficient for fatty acid stimulation of insulin secretion in vivo. Diabetes 2007; 56(4):1087-1094.

(129) Itoh Y, Kawamata Y, Harada M, Kobayashi M, Fujii R, Fukusumi S, Ogi K, Hosoya M, Tanaka Y, Uejima H, Tanaka H, Maruyama M, Satoh R, Okubo S, Kizawa H, Komatsu H, Matsumura F, Noguchi Y, Shinohara T, Hinuma S, Fujisawa Y, Fujino M: 
Free fatty acids regulate insulin secretion from pancreatic beta cells through GPR40. Nature 2003; 422(6928):173-176.

(130) Hirasawa A, Tsumaya K, Awaji T, Katsuma S, Adachi T, Yamada M, Sugimoto Y, Miyazaki S, Tsujimoto G: Free fatty acids regulate gut incretin glucagon-like peptide1 secretion through GPR120. Nat Med 2005; 11(1):90-94.

(131) Tanaka T, Yano T, Adachi T, Koshimizu TA, Hirasawa A, Tsujimoto G: Cloning and characterization of the rat free fatty acid receptor GPR120: in vivo effect of the natural ligand on GLP-1 secretion and proliferation of pancreatic beta cells. Naunyn Schmiedebergs Arch Pharmacol 2008; 377(4-6):515-522.

(132) Tanaka T, Katsuma S, Adachi T, Koshimizu TA, Hirasawa A, Tsujimoto G: Free fatty acids induce cholecystokinin secretion through GPR120. Naunyn Schmiedebergs Arch Pharmacol 2008; 377(4-6):523-527.

(133) Parker HE, Habib AM, Rogers GJ, Gribble FM, Reimann F: Nutrient-dependent secretion of glucose-dependent insulinotropic polypeptide from primary murine $\mathrm{K}$ cells. Diabetologia 2009; 52(2):289-298.

(134) Miyauchi S, Hirasawa A, Iga T, Liu N, Itsubo C, Sadakane K, Hara T, Tsujimoto G: Distribution and regulation of protein expression of the free fatty acid receptor GPR120. Naunyn Schmiedebergs Arch Pharmacol 2009; 379(4):427-434.

(135) Hirasawa A, Tsumaya K, Awaji T, Katsuma S, Adachi T, Yamada M, Sugimoto Y, Miyazaki S, Tsujimoto G: Free fatty acids regulate gut incretin glucagon-like peptide1 secretion through GPR120. Nat Med 2005; 11(1):90-94.

(136) Wellendorph P, Johansen LD, Brauner-Osborne H: Molecular pharmacology of promiscuous 7TM receptors sensing organic nutrients. Mol Pharmacol 2009.

(137) Hirasawa A, Tsumaya K, Awaji T, Katsuma S, Adachi T, Yamada M, Sugimoto Y, Miyazaki S, Tsujimoto G: Free fatty acids regulate gut incretin glucagon-like peptide1 secretion through GPR120. Nat Med 2005; 11(1):90-94.

(138) Hirasawa A, Tsumaya K, Awaji T, Katsuma S, Adachi T, Yamada M, Sugimoto $Y$, Miyazaki S, Tsujimoto G: Free fatty acids regulate gut incretin glucagon-like peptide1 secretion through GPR120. Nat Med 2005; 11(1):90-94.

(139) Hara T, Hirasawa A, Sun Q, Sadakane K, Itsubo C, Iga T, Adachi T, Koshimizu TA, Hashimoto T, Asakawa Y, Tsujimoto G: Novel selective ligands for free fatty acid receptors GPR120 and GPR40. Naunyn Schmiedebergs Arch Pharmacol 2009.

(140) Katsuma S, Hatae N, Yano T, Ruike Y, Kimura M, Hirasawa A, Tsujimoto G: Free fatty acids inhibit serum deprivation-induced apoptosis through GPR120 in a murine enteroendocrine cell line STC-1. J Biol Chem 2005; 280(20):19507-19515.

(141) Hara T, Hirasawa A, Sun Q, Sadakane K, Itsubo C, Iga T, Adachi T, Koshimizu TA, Hashimoto T, Asakawa Y, Tsujimoto G: Novel selective ligands for free fatty acid receptors GPR120 and GPR40. Naunyn Schmiedebergs Arch Pharmacol 2009.

(142) Katsuma S, Hatae N, Yano T, Ruike Y, Kimura M, Hirasawa A, Tsujimoto G: Free fatty acids inhibit serum deprivation-induced apoptosis through GPR120 in a murine enteroendocrine cell line STC-1. J Biol Chem 2005; 280(20):19507-19515. 
(143) Katsuma S, Hatae N, Yano T, Ruike Y, Kimura M, Hirasawa A, Tsujimoto G: Free fatty acids inhibit serum deprivation-induced apoptosis through GPR120 in a murine enteroendocrine cell line STC-1. J Biol Chem 2005; 280(20):19507-19515.

(144) Dhayal S, Welters HJ, Morgan NG: Structural requirements for the cytoprotective actions of mono-unsaturated fatty acids in the pancreatic beta-cell line, BRIN-BD11. Br J Pharmacol 2008; 153(8):1718-1727.

(145) Morgan NG, Dhayal S, Diakogiannaki E, Welters HJ: The cytoprotective actions of long-chain mono-unsaturated fatty acids in pancreatic beta-cells. Biochem Soc Trans 2008; 36(Pt 5):905-908.

(146) Dhayal S, Welters HJ, Morgan NG: Structural requirements for the cytoprotective actions of mono-unsaturated fatty acids in the pancreatic beta-cell line, BRIN-BD11. Br J Pharmacol 2008; 153(8):1718-1727. 


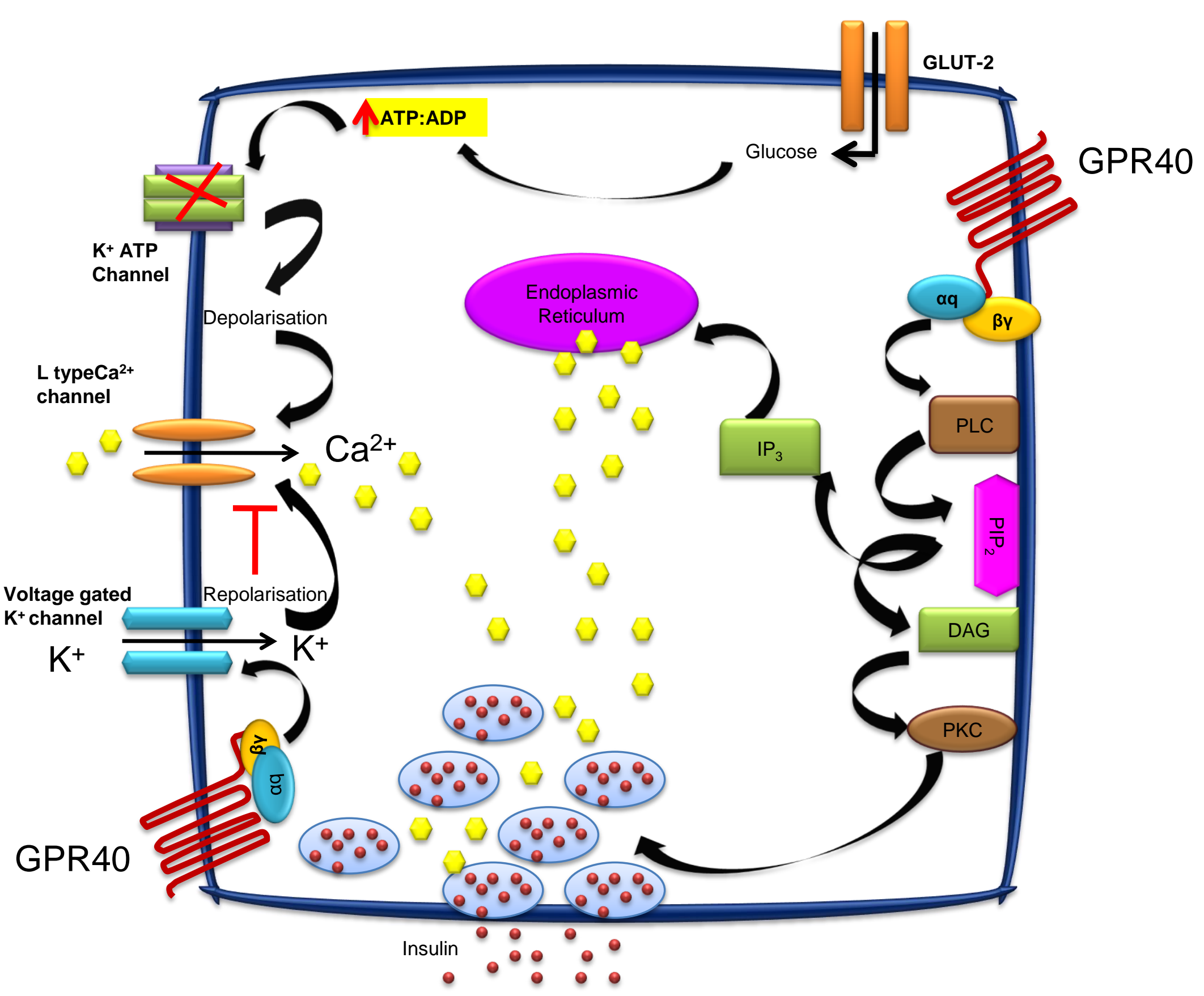


2.

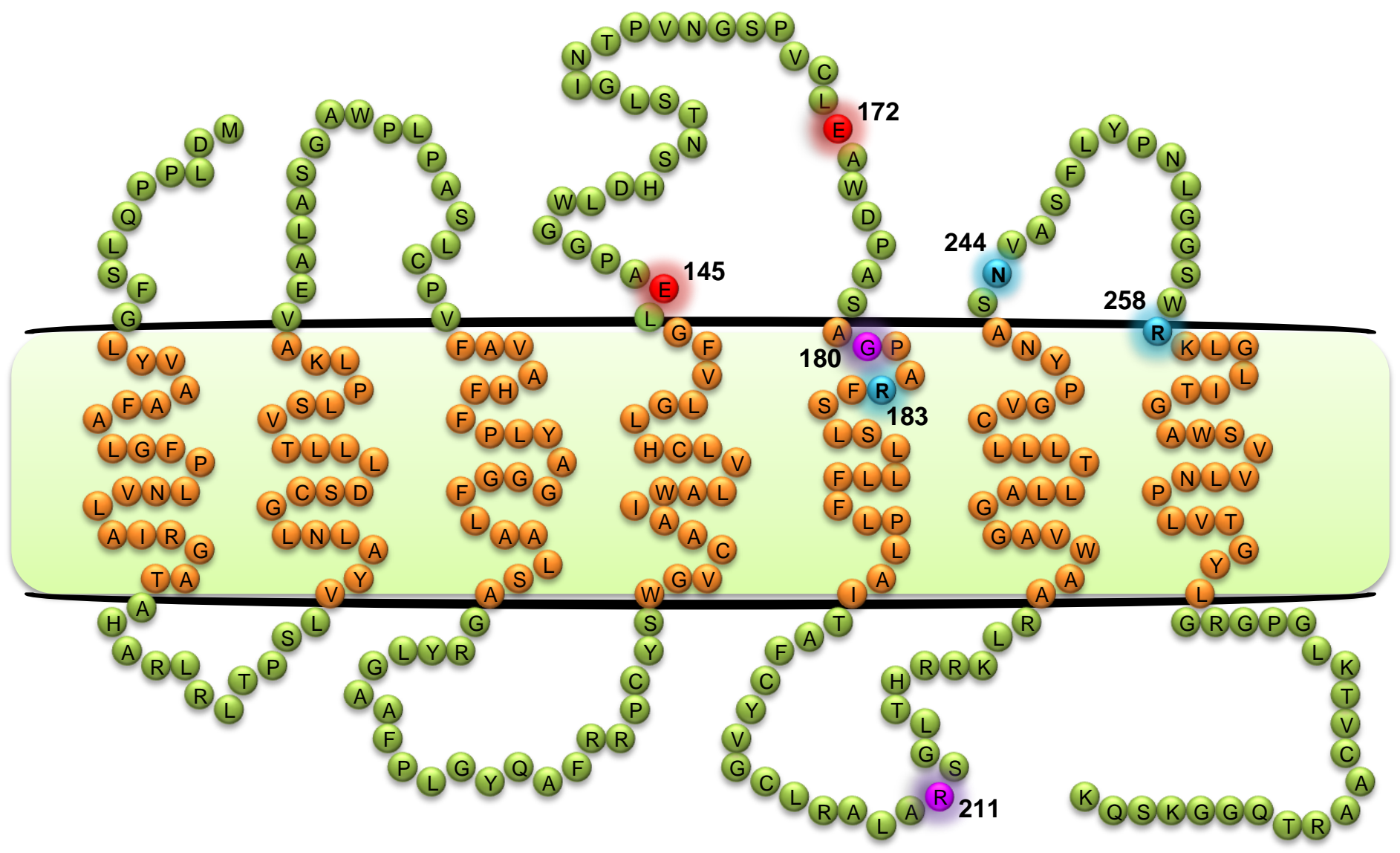


